\title{
Hong Kong by night: Prostitution and cinema in herman Yau's Whispers and Moans
}

\section{Sebastian Veg}

\section{(2) OpenEdition}

\section{Journals}

Édition électronique

URL : http://journals.openedition.org/chinaperspectives/1773

DOI : 10.4000/chinaperspectives. 1773

ISSN : 1996-4617

Éditeur

Centre d'étude français sur la Chine contemporaine

\section{Édition imprimée}

Date de publication : 15 avril 2007

ISSN : 2070-3449

Référence électronique

Sebastian Veg, "Hong Kong by night: Prostitution and cinema in herman Yau's Whispers and Moans », China Perspectives [En ligne], 2007/2 | 2007, mis en ligne le 08 avril 2008, consulté le 10 décembre 2020. URL : http://journals.openedition.org/chinaperspectives/1773 ; DOI : https://doi.org/10.4000/ chinaperspectives. 1773 


\title{
Hong Kong by Night:
}

\author{
Prostitution and Cinema in Herman Yau's Whispers and Moans
}

\author{
SEBASTIAN VEG
}

$\mathrm{H}$ erman Yau's new film, Whispers and Moans, sketches the portrait of a parallel and colourful universe, rarely advertised to foreign visitors (although well known to some): the world of prostitution. While Yau is mainly known for his horror films (The Untold Story, 1993) or Hong Kong-style action movies (recently, On the Edge), he also regularly works with Yang Yeeshan (Elsa Chan), to produce social films in a more documentary vein, such as From the Queen to the Chief Executive (2001) about the detention of juvenile delinquents-conceived as a kind of counterpoint to stories of the handover ${ }^{(1)}$. Whispers and Moans is also adapted from an investigative study by Yang Yeeshan of prostitution in Hong Kong, published in Chinese under the title Xing gongzuozhe shiri tan (Ten Days of Discussions with Sex Workers).

By using the same title for the film, Yau gives an indication of its polyphonic, non-linear structure. Rather than a story, Yau films fragments of lives, which gradually come together to form individual portraits, as the main characters weave in and out of the picture. These movements take place against the backdrop of two main settings: a call-girl club, strictly regulated by two "mama-sans" (Jenny and Coco), where the "girls" that the film is about work, and a casino where women can hire the services of young men for similar entertainment. The first narrative thread links a series of scenes revolving around sexually transmitted diseases. A producer of pornographic films, who supports Coco and at the same time patronises a transsexual named Jo (played by the well-known actor Don Li Yat-long), succumbs to syphilis. Jo panics, hesitating whether to have a test, whereas Coco immediately tests for HIV. Nevertheless, the theme is not approached in a tragic manner as neither of the characters is contaminated; much rather it is thanks to the test that Jo meets Tony, a callboy from the casino, who becomes his lover. The theme returns when Coco finds the two men together in the producer's apartment and, learning that the producer was infected with syphilis, returns to the doctor in panic for another test. Illustrating the pervasive fear of contamination, she in turn frightens and angers her colleague Happy (originally from the mainland), who prides herself on having worked for seven years without having exposed herself to any risk of contamination.
The relationship between Tony and Jo is another narrative thread of the film, as Tony's character is used to embody the reversibility of all situations, which serves to give the film its unconventional structure. The spectator discovers him in the first scene as the "gigolo of Causeway Bay," whose vexations the girls in the club are obliged to endure because he pays them. It later transpires that he uses these sprees as a means to take out on them his humiliation at having to serve as "bait" night after night for the two women regularly entertained by the boss of the casino, where he works. The scene in which Jo sees him soliciting another prostitute on the street to humiliate her entails a dispute with subtle repercussions. And at the end, the roles are reversed, when Tony is in turn tortured while "on duty" by being forced to drink wine by the bottle until he can literally no longer hold it down. Shortly before the end of the film, Happy hires him for a night to celebrate her quitting the profession to return to Harbin, where she is to become vice-principal of a school (sponsored by the boss of the casino). This reference to China's north-east and to migrant sex workers from the mainland hoping to strike it rich in Hong Kong is probably an allusion to Fruit Chan's film Durian, Durian (2000), one of the first to address the issue. The end of Yau's film introduces an unforeseen tragic note: while all characters are able to dodge between the drops of the diseases that appear in the film, Tony is ultimately beaten up and stabbed repeatedly in the street, and the spectator leaves him between life and death.

On one level, the film serves to reveal many of Hong Kong's social problems. Tony mocks a newly arrived prostitute from the mainland who makes advances to him on the street (assuring him that she will "satisfy" him, she pronounces manyi 滿意 in Mandarin) by retorting that she should start by learning Cantonese ${ }^{(2)}$. Social hypocrisy is also depicted through the character Nana, whose friend Eric knows noth-

1. See the useful publication by the Hong Kong International Film Festival (edited by Keith Chan and Li Cheuk-to), Herman Yau (Yau Lai-to), Director in Focus, Hong Kong, 2007.

2. Another interesting recent film on the wave of immigration from the mainland to Hong Kong is August Story by Yan Yan Mak, shot in a similar vein to Love will tear us apart (Tin sheung yan gaan) by Yu Lik Wai (1999), in which one of the characters is also a sex worker originally from the mainland. 
ing of her night-time activities. Eric is seemingly caught in the trap of the conventionality of his own dreams, as Nana sneaks out of the restaurant where he proposes to her because the idea of a banquet with at least thirty tables for his family alone triggers the thought that she might meet one of her customers. Similarly, Coco, one of the "mama-sans" at the club, tries to make her daughter (who lives with her grandmother) believe that she is living a normal life. Finally, the character Aida, Nana's sworn sister, illustrates the hierarchy of the world of sex workers. Because she is unable to break her dependency on drugs, Aida is forced to leave the club, then again to leave the semi-private brothel where Nana finds work for her, and ends up on the street at Yau Ma Tei, practising the type of prostitution known as "one room one woman" (yat lau yat fong 一樓一鳳)-the lowest, most precarious and most dangerous variant of the profession ${ }^{(3)}$.

Nonetheless, the issue of the observer's gaze is not a blind spot in the film. This is the justification for the appearance of Elsie, a young and naive anthropologist trying to distribute leaflets and condoms at the door of the club, who is ignored or snubbed by the women working there. Finally, when she does Happy a favour by testifying in front of a policeman that she has not "solicited" anyone on the street, Happy allows her to enter the club. The director in this way no doubt denounces Hong Kong's laws on "soliciting for immoral purposes" and the current crackdown by the police, which criminalises the estimated 200,000 sex workers active in Hong Kong, in particular the migrant workers who are victims of human trafficking ${ }^{(4)}$. But at the same time, Yau questions the somewhat naive beliefs of activists who think that calling prostitutes "sex workers" (xing gongzuozhe 性工作者) will solve their problems by making them "proud of their work." Elsie thus repeats the word "sex worker" ad absurdum, and Jenny is perhaps not wrong in saying that it humiliates prostitutes even more by reminding them of the purely sexual nature of their work; Coco on the contrary asserts in a cheering tirade that she has never had as much fun as when she was a prostitute. Through the figure of Elsie, Herman Yau of course raises the question of the legitimacy of the observer's discourse.

For this reason, the film should probably be seen first and foremost as a depiction, in and through cinema, of the shady, nocturnal side of Hong Kong which is the backdrop for Yau's gangster films. The club's Indian doorman, his head wrapped in a huge red turban, the individual parlours decorated with bright mirrors and the sparkling casino where Tony works are commonplaces of Hong Kong cinema. An amusing detail in this respect is that Whispers and Moans received a category III rating (over 18), despite the absence of any explicit sexu-

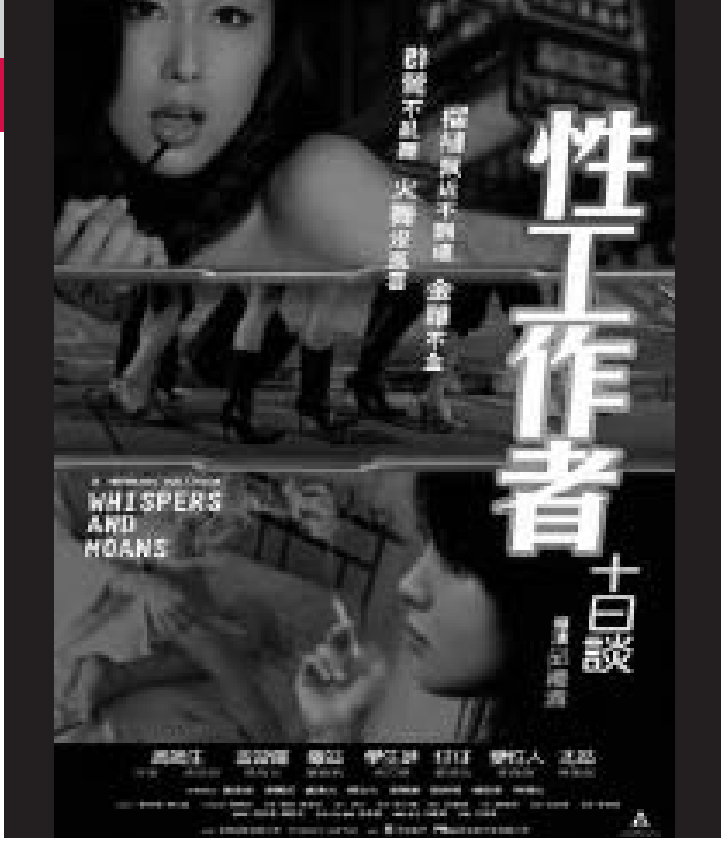

al scene. For this reason, it was distributed in cinemas (like the Tsim Sha Tsui Chinachem), which are in very close spatial and sociological continuity with the setting of the film. In any event, it is only the director's interest in this nocturnal side of Hong Kong that can explain the nostalgia entailed by the closing of the club, which at the end of the film falls victim to mainland competition, in what has been interpreted by some critics as a metaphor for the future of Hong Kong cinema.

All in all, Herman Yau has been successful in staging endless reversals of roles and situations: while prostitution initially appears as a social problem of discrimination and pauperisation, it is progressively diffracted into a variety of individual portraits. In this way, the "girls" in the film come across as both ordinary people and as individuals too strong to tally with a unifying discourse on their work or their beliefs. In this way, at the end of the "ten days," the viewer does not know whether to feel empathy with this modern proletariat or to envy it, whether to make it an object of study or of political activism. Rather than Elsie's objectifying but overly idealistic gaze, it is cinema which in this case lends dignity and charisma to the characters it depicts. Herman Yau questions the cohesiveness of Hong Kong's society, its fascination with appearances and bright neon lights; its infiltration by triads, and the patronising of call-girl clubs and bars by businessmen or drop-outs alike. But by constructing his film as a series of questions without answers, Yau meets the challenge of showing the fascination held by the shady world of clubs and prostitutes in Kowloon without romanticising it. Just like the Hong Kong of gangster films, this universe is not separable from the identity of the city, very much like cinema itself, which creates and shapes as much as it documents it.

3. This is the only form of prostitution that does not fall within the law on "vice establishments," housing at least two persons. Samson Chiu's film Golden Chicken (2002) was devoted to this issue.

4. See also Simon Parry, "Caught in the Act," South China Morning Post Magazine, 3 June 2007 , p. 12-16. This article is precisely devoted to the debate triggered by the revelation that police officers could hire the services of prostitutes within their duties and with public funding, officially to provide evidence by catching prostitutes "in the act." The denunciation of this practice by the NGO Ziteng (www.ziteng.org.hk) is another example of the relative vitality of Hong Kong civil society. 